Archives of Agriculture and Environmental Science

\title{
Health risk assessment of heavy metals via dietary intake of vegetables grown in wastewater irrigated areas of Jagjeetpur, Haridwar India
}

\section{Vinod Kumar and Roushan K. Thakur}

Agro-ecology and Pollution Research Laboratory, Department of Zoology and Environmental Sciences, Gurukula Kangri Vishwavidyalyaya, Haridwar- 249404 (Uttarakhand), INDIA

*Corresponding author's E-mail:rthakur_rs@gkv.ac.in iD

\section{ARTICLE HISTORY}

Received: 12 December 2017

Revised received: 15 February 2018

Accepted: 20 February 2018

\section{Keywords}

Dietary intake

Heavy metals

Human health risk

Soil

Vegetables

Wastewater

\section{ABSTRACT}

The present study was conducted to appraise the human health risk due to dietary intake of heavy metals contaminated vegetables viz., cabbage (Brassica oleracea var. capitata), cauliflower (Brassica oleracea var. botrytis) and spinach, (Spinacia oleracea) grown in the municipal wastewater irrigated soil in the proximity of sewage treatment plant (STP), Jagjeetpur, Haridwar. The results showed that $\mathrm{Cd}$, Fe and $\mathrm{Mn}$ concentrations in B. oleracea var. capitata, $B$. oleracea var. botrytis and S. oleracea were found beyond the safe limit of the Indian and WHO/ FAO standards for heavy metals in the vegetables. The contamination factor of these heavy metals in the soil was recorded in the order of $\mathrm{Fe}>\mathrm{Mn}>\mathrm{Zn}>\mathrm{Cu}>\mathrm{Cr}>\mathrm{Cd}$ after irrigation of municipal wastewater. The higher values of metal pollution index in different vegetables as $B$. oleracea var. capitata (14.82; B. oleracea var. botrytis (10.48) and S. oleracea (12.59) showed more health risk index for $\mathrm{Cd}$, Fe and $\mathrm{Mn}$ in these vegetables cultivated in the wastewater irrigated soil. Therefore, dietary intake of these heavy metals contaminated vegetables may pose a significant threat to the human health. However, cauliflower contained less heavy metal as compared to the cabbage and spinach, but health risk was more due to higher role in the diet. Even though there were low concentrations of heavy metals in the municipal wastewater used for the irrigation, but long term use of the municipal wastewater may cause gradual buildup of heavy metals in the vegetables grown in the municipal wastewater irrigated soil and leads to health risk of consumers due to intake of heavy metals contaminated vegetables.

(C)2018 Agriculture and Environmental Science Academy

Citation of this article: Kumar, V. and Thakur, R.K. (2018). Health risk assessment of heavy metals via dietary intake of vegetables grown in wastewater irrigated areas of Jagjeetpur, Haridwar India. Archives of Agriculture and Environmental Science, 3(1): 73-80 DOI: 10.26832/24566632.2018.0301011

\section{INTRODUCTION}

Wastewater irrigation is a collective realism in three-fourth of the cities in Asia, Africa and Latin America. Wastewater conveys substantial amounts of trace toxic metals (Pescod 1992; Yadav et al., 2002). Wastewater irrigation is known to have its significant impact to the heavy metal content of soils (Mapanda et al., 2005; Nan et al., 2002). This charging of heavy metals often clues to degradation of soil health and adulteration of food chain mainly through the vegetables grownup on such soils (Rattan et al., 2002). Most municipal farmers in India use wastewater rich in harmful heavy metals alike cadmium (Cd), chromium ( $\mathrm{Cr}$ ), copper ( $\mathrm{Cu}$ ), iron (Fe), nickel (Ni), manganese $(\mathrm{Mn})$, lead $(\mathrm{Pb})$ and zinc $(\mathrm{Zn})$ and biological negotiators such as pathogenic bacteria, coliform bacteria fungi, protozoans and nematodes etc. and this poses serious health pressures, such as a risk of biomagnifications of heavy metals and conveying intestinal nematodes and bacterial infections especially to consumers and farm hands (Manios et al., 2006; Zhang et al., 2008; Pathak et al., 2011; Kumar et al., 2015, 2017).

Heavy metals are usually not removed even after the treatment of wastewater at sewage treatment plants, and thus cause threat of heavy metal adulteration of the soil and consequently to the food chain (Fytianos et al., 2001). Consumption of heavy 
metals through the food chain by human populations has been widely testified throughout the biosphere (Muchuweti et al., 2006). Due to the non-biodegradable and persistent nature, heavy metals are accrued in vital organs in the humanoid body such as the kidneys, bones and liver and are linked with numerous serious health syndromes (Duruibe et al., 2007; Kumar and Thakur, 2017). Individual metals display specific signs of their toxicity. Lead, As, $\mathrm{Hg}, \mathrm{Zn}, \mathrm{Cu}$ and $\mathrm{Al}$ poisoning have been concerned with gastrointestinal (GI) disorders, diarrhoea, stomatitis, tremor, hemoglobinuria causing a rust-red colour to stool, ataxia, paralysis, spewing and convulsion, depression, and pneumonia (McCluggage, 1991; Raj and Thakur, 2017).

Undeniably, there is no way to stop wastewater use by the farmers, but we can try and make their usage safer by reviewing parts of crops that gather the least heavy metals and thus recommend the farmers and consumers on which parts of the crops is nontoxic to eat (Rattan et al., 2005; Ambika et al., 2010; Kumar and Chopra, 2013 and Kumar et al., 2015, 2016). For farmed soil, irrigation with sewage and application of wastewater will raise crop production because of appreciated sources of vegetable nutrients and organic matter. Another reason for irrigation with wastewater is severe famine of renewed water (Wang and Lin, 2003; Mireles et al., 2004; Singh et al., 2012). However, there are many kinds of heavy metals in wastewater that may be accrued in soil with long-term use. Though, wastewater had a positive effect for short-term submission, heavy metal contaminations with long-term practice of wastewater (Nanjundappa et al., 2002; Oliveira and Pampulha, 2006; Singh et al., 2012).

Vegetables are major constituents of human diet, being sources of key nutrients, antioxidants and metabolites in food items (Kumar et al., 2015). In the current study, the attentions of heavy metals in locally produced vegetables were determined throughout a harvesting period at a peripheral area of Haridwar city of India, where treated and untreated wastewater has been recycled as a source of irrigation water for about 20 years (Kumar et al., 2016). The contamination levels in soil and vegetable crops were evaluated with respect to the prescribed safe limits of different heavy metals set under national and international norms. A number of standard measures were used to assess the health risks associated with the measured levels of heavy metal adulteration at the study sites. Therefore the present study was carried out to assess the health risk assessment of heavy metals via dietary intake of vegetables grown in wastewater irrigated areas of Jagjeetpur, Haridwar India.

\section{MATERIALS AND METHODS}

\section{Study sites}

The study was conducted around Jagjeetpur sewage treatment plant (JSTP) situated at suburban area in the Haridwar district

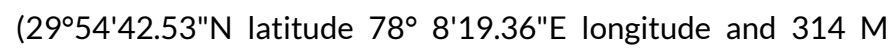
above the sea level). Large-scale vegetables production is carried out in this area and maximum amount of these vegetables is supplied in the market of the Haridwar city. Industrial effluents from various small scale industries positioned in the city are also discharged along with municipal sewage for the treatment at JSTP. These industries include fabric portrait, batteries, dye, plastic recycling and metal surface treatment. A large area around JSTP has no access to sanitary water resources, so farmers use treated and untreated wastewater for irrigation of their crops. During the present study, two major sites were demarcated in Jagjeetpur having different irrigation practices. At the wastewater irrigated (WWI) site, treated wastewater from JSTP has been used for irrigating the fields for about 20 years. Sometimes due to power failure or technical issue the sewage treatment plant does not work and untreated wastewater is used for irrigation. Clean water from bore wells has been used for watering the agricultural fields at the clean water irrigated site (CWI) for a similar period of time.

\section{Soil and water sampling}

Soil and water samples were collected at fortnightly interval from September 2016 to March 2017. Soil samples were collected in triplicate by digging out a monolith of $10 \times 10 \times 15$ $\mathrm{cm}^{3}$ size, from 10 subsites of both clean (CWI) and wastewater irrigated sites (WWI). Soil samples were air-dried, crumpled and passed through $2 \mathrm{~mm}$ mesh size sieve and stored at ambient temperature before analysis. Both clean and wastewater samples (100 $\mathrm{ml}$ ) used for irrigation were composed in triplicate in a pre-acid washed polypropylene bottle and $1 \mathrm{ml}$ of concentrated $\mathrm{HNO}_{3}$ was added in the water sample to escape the microbial action. These samples were carried back to the laboratory and kept in a refrigerator before digestion.

\section{Plant sampling}

All the vegetables viz., cabbage (Brassica oleracea var. capitata), cauliflower (Brassica oleracea var. botrytis) and spinach, (Spinacia oleracea) crops grown in the experimental area were collected either for home feasting or sale. The details of different plants sampled during the experiment are given in Table 1. An area of $5 \times 5 \mathrm{~m}^{2}$ was indiscriminately marked at 10 sub sites in triplicate and the eatable portion of test vegetables were collected from both CWI and WWI sites. Samples were brought back to the laboratory and wash away with clean tap water to remove the soil elements adhered to the surface of the vegetables. After removing the extra water from the surface of vegetables with blotting paper, samples were cut into pieces, packed into separate bags, and kept in an oven until a constant weight was achieved. The dried samples were grinded and passed through a sieve of $2 \mathrm{~mm}$ size and then kept at room temperature for further analysis.

\section{Analytical methods}

The irrigation water sample $(50 \mathrm{ml})$ was digested with $10 \mathrm{ml}$ of concentrated $\mathrm{HNO}_{3}$ at $80^{\circ} \mathrm{C}$ until the solution became transparent (APHA, 2012). The solution was sieved through Whatman No. 42 filter paper and the total volume was sustained to $50 \mathrm{ml}$ with distilled water. Vegetables and soil samples were digested in di acid (2:1 ratio of $\mathrm{HNO}_{3}$ and $\left.\mathrm{HClO}_{4}\right)$ as per the method described in AOAC (1990) for wet washing. $0.5 \mathrm{~g}$ of powdered 
samples of vegetable, soil and water $(10 \mathrm{ml})$ were taken in digestion tube and then $10 \mathrm{ml}$ nitric acid $\left(\mathrm{HNO}_{3}\right)$ and $5 \mathrm{ml}$ perchloric acid $\left(\mathrm{HClO}_{4}\right)$ were added and the digestions were completed on digestion blocks (Make FOSS) following standard measures as described by Chaturvedi and Sankar (2006). After digestion all samples were sieved through Whatman 42 filter paper and volume was made up to $50 \mathrm{ml}$. Heavy metals such as $\mathrm{Cr}, \mathrm{Cd}, \mathrm{Cu}, \mathrm{Fe}$, $\mathrm{Mn}$, and $\mathrm{Zn}$ in the digested aliquot were determined by atomic absorption spectrophotometer (Perkin-Elemer model 5000).

\section{Data analysis}

Enrichment factor (EF): To examine the translocation of heavy metals in the soil and in the edible portion of test plants, and to show the difference in metal concentrations in the plants between the sites, the enrichment factor (EF) was calculated by using the formula given by Buat-Menard and Chesselet (1979):

\section{Concentation of heavy metals in edible part at WWI site $\mathrm{EF}=$ Concentation of heavy metals in soil at WW \\ Concentation of heavy metals in edible part at CWI site Concentation of heavy metals in soil at CWI site}

Metal pollution index (MPI): To examine the overall heavy metal concentrations in all crops analysed in the wastewater irrigated site, metal pollution index (MPI) was computed. This index was obtained by calculating the geometrical mean of concentrations of all the metals in the vegetables, cereals and milk (Usero et al., 1997).

$$
\operatorname{MPI}\left(\mu \mathrm{gg}^{-1}\right)=\left(\mathrm{Cf}_{1} \times \mathrm{Cf}_{2} \times \ldots \ldots \ldots . . . \times \mathrm{Cf}_{n}\right)^{1 / n}
$$

Where $\mathrm{Cf}_{\mathrm{n}}=$ concentration of metal $\mathrm{n}$ in the sample.

Health risk index (HRI): The health risk index was calculated as the ratio of estimated exposure of test crops and oral reference dose (Cui et al., 2004). Oral reference doses were $4 \times 10^{-2}, 0.3$ and $1 \times 10^{-3} \mathrm{mg} \mathrm{kg}^{-1} \mathrm{day}^{-1}$ for $\mathrm{Cu}, \mathrm{Zn}$ and Cd, respectively (USEPA, 2002) and $0.004,0.02$ and $1.5 \mathrm{mg} \mathrm{kg}^{-1} \mathrm{day}^{-1}$ for $\mathrm{Pb}, \mathrm{Ni}$ and $\mathrm{Cr}$, respectively (USEPA, 1997). Estimated exposure is obtained by dividing daily intake of heavy metals by their safe limits. An index more than 1 is considered as not safe for human health (USEPA, 2002).

Daily intake was calculated by the following equation:

$$
\text { Daily intake of metal }(D I M)=\frac{C_{\text {metal }} \times D_{\text {food intake }}}{B_{\text {average weight }}}
$$

Where $C$ metals $D$ foodintake and $B$ averageweight represent the heavy metal concentrations in plants $\left(\mu \mathrm{g} \mathrm{g}^{-1}\right)$, daily intake of vegetables and average body weight, respectively. The average daily vegetable intake rate was calculated by conducting a survey where 100 people having average body weight of $60 \mathrm{~kg}$ were asked for their daily intake of particular vegetable from the experimental area in each month of sampling (Ge, 1992; Wang et al., 2005).

\section{Statistical analysis}

The significance of differences between the concentrations of heavy metals in soil at wastewater (WWI) and clean water irrigated (CWI) sites were shown by using Student's t-test. The data of heavy metal concentrations in the plants at different sites were subjected to two-way analysis of variance (ANOVA) test for assessing the significance of differences in heavy metal concentrations due to different irrigation practices. All the statistical tests were performed using SPSS software (SPSS Ins., version 11).

\section{RESULTS AND DISCUSSION}

Levels of heavy metals in water samples

The attentions $\left(\mathrm{\mu gml}^{-1}\right.$ ) of heavy metals in the irrigation water at WWI site ranged between 0.03-0.08 for $\mathrm{Cr}, 0.00-0.02$ for $\mathrm{Cd}$, 0.02-0.07 for $\mathrm{Cu}, 0.47-1.03$ for $\mathrm{Fe}, 0.15-0.28$ for $\mathrm{Mn}$ and 0.050.18 for Zn during September 2016 to March 2017, whereas at $\mathrm{CWI}$ site, heavy metal concentrations in irrigation water were very low or below the noticeable limits (Figure 1). Heavy metals in the sewage water are related with small-scale industries such as colouring, electroplating, metal surface treatments, fabric printing, battery and paints, releasing $\mathrm{Cd}, \mathrm{Cu}, \mathrm{Fe}, \mathrm{Mn}, \mathrm{Zn}$ and other heavy metals into water channels, which are accessed for irrigation. As compared to the present concentration of heavy metals in the wastewater, Kumar et al. (2016) reported Fe (1.72) and $\mathrm{Zn}(0.38)$ in the sewage effluent were found very low or below prescribed limit.

\section{Levels of heavy metals in the soil}

Eminent levels of heavy metals in irrigation water led to suggestively higher concentrations of heavy metals in the soil at WWI site as compared to those acquired from clean water irrigated site (Table 2). The heavy metal absorptions were, still below the safe limits of Indian standards (Awashthi, 2000) and EU standards (European Union, 2002) at WWI site (Table 2). The lower availability of heavy metals than the safe limits at WWI site may be due to the constant abstraction of heavy metals by the vegetables grown up in this area and also due to percolating of heavy metals into the deeper layer of the soil. The increases in the heavy metal attentions in the soil were $226 \%$ for $\mathrm{Cr}, 274 \%$ for $\mathrm{Cd}, 263 \%$ for $\mathrm{Cu}, 583 \%$ for $\mathrm{Fe}, 480 \%$ for $\mathrm{Mn}$ and $322 \%$ for $\mathrm{Zn}$ at WWI site as compared to CWI site in the present study (Table 2).The contamination factor of heavy metals in the soil was recorded in the order of $\mathrm{Fe}>\mathrm{Mn}>\mathrm{Zn}>\mathrm{Cu}>\mathrm{Cr}>\mathrm{Cd}$ after disposal of wastewater. Additionally, the increase in the contents of Fe, $\mathrm{Mn}, \mathrm{Zn}, \mathrm{Cu}, \mathrm{Cr}$ and $\mathrm{Cd}$ are likely due to the presence of more concentration of these metals in the wastewater.

\section{Content of heavy metals in the plants}

Heavy metal concentrations showed variations among different vegetables collected from CWI and WWI irrigated sites (Figure 2). The results showed that the contents of $\mathrm{Cu}(r=+0.91)$ and 
$\mathrm{Mn}(r=+0.74)$ in the edible parts of cabbage were found to be positively correlated and contents of $\mathrm{Cd}(r=-0.62), \mathrm{Cr}(r=-0.68)$, Fe $(r=-0.34)$ and $\mathrm{Zn}(r=-0.98)$ were found to be negatively correlated, Cauliflower showed slightly negative correlation with $\mathrm{Cr}$ and $\mathrm{Cd}(r=-0.06$ and -0.06$)$ and showed moderately correlation with $\mathrm{Cu}(r=+0.67)$ and Spinach showed positively correlated with all the metals except $\mathrm{Zn}(r=-0.22)$ with the content of $\mathrm{Cd}, \mathrm{Cr}, \mathrm{Cu}$, $\mathrm{Fe}, \mathrm{Mn}$ and $\mathrm{Zn}$ recorded in the soil (Table 4). The metals in plants were translocated capably from the soil through root system. The higher content of these metals in the soil is likely due to the presence of more contents of the metals in the sewage effluent, used for the irrigation of cabbage in the present study. Kumar et al. (2015) also reported the significant correlation of different heavy metals in the different vegetables viz., carrot (Daucus carota), radish (Raphanus sativus), beet root (Beta vulgaris) and sweet potato (Ipomoea batatas) grown in municipal wastewater.

Results of two-way ANOVA test showed that variations in the heavy metal absorptions were significant due to site, plant and site plant interaction $(P<0.05 / P<0.01 / P<0.001)$. The dissimilarities in heavy metal attentions in vegetables of the same site may be ascribed to the differences in their morphology and physiology for heavy metal uptake, accumulation and retention (CarltonSmith and Davis, 1983; Kumar et al., 2009). Several-fold higher absorptions of all the heavy metals were observed in all the vegetables at WWI site as compared to CWI site. The use of adulterated irrigation water at WWI site increased the uptake and accretion of the heavy metals in the plants. This is consistent with reports of higher availability of heavy metals in vegetables from sewage water irrigated areas as compared to the sewage treatment plant STP water irrigated areas of Sarai village of Haridwar (Kumar et al., 2015).

\section{Enrichment factor}

Higher values of enrichment factor (EF) suggest poor retention of metals in soil and/or more translocation in plants. Within the plants, cabbage and spinach (leafy vegetable) showed highest EF values for Cd and Fe (Table 5). Fytianos et al. (2001) have reported higher enrichment factor for $\mathrm{Cd}$ through leafy vegetables. Sridhara Chary et al. (2008) also reported highest enrichment factor for heavy metals through leafy vegetables. Enrichment factor of heavy metals depends upon bioavailability of metals, which in turn depends upon its concentration in the soil, their chemical forms, difference in uptake capability and growth rate of different plant species (Tinker, 1981). The higher uptake of heavy metals in leafy vegetables may be due to higher transpiration rate to maintain the growth and moisture content of these plants (Tani and Barrington, 2005).

\section{Metal pollution index (MPI)}

Metal pollution index (MPI) is suggested to be a reliable and precise method for metal pollution monitoring of wastewater irrigated areas (Usero et al., 1997). Among different vegetables, cabbage showed highest value of MPI followed by spinach. As compared to the cauliflower, cabbage and spinach showed higher metal pollution index (Figure 3). Higher MPI of cabbage, cauliflower and spinach suggests that these vegetables may cause more human health risk due to higher accumulation of heavy metals in the edible portion. To assess the health risk associated with heavy metal contamination of plants grown locally, estimated exposure and risk index were calculated. The results showed that $\mathrm{Cd}$, Fe and $\mathrm{Mn}$ contamination in plants had greatest potential to pose health risk to the consumers (Table 6). Health risk index was more than 1 for all the vegetables, only the health risk index for $\mathrm{Cu}$ was less than 1 except in cauliflower. Although, cauliflower have lesser concentrations of metals than other two vegetables, but the health risk index was higher. In the present study, only $\mathrm{Cu}$ was not found to cause any risk to the local population. Cui et al., (2004) have also reported that local residents of an area near a smelter in Nanning, China have been exposed to $\mathrm{Cd}$ and $\mathrm{Pb}$ through consumption of vegetables, but no risk was found due to $\mathrm{Cu}$ and $\mathrm{Zn}$. Metal transfer factor from soil to plants is a crucial component of human exposure to heavy metals via food chain. Transfer aspect of metals is essential to investigate the human health risk index (Cui et al., 2004).

Table 1. Plant samples collected from the experimental sites.

\begin{tabular}{llll}
\hline Edible part of vegetable & Common name & Botanical name & Family \\
\hline Leaf & Spinach & Beta vulgaris L. & Chenopodiaceae \\
Leaf & Cabbage & Brasssicaoleracea L. var. capitata L. & Brassicaceae \\
Inflorescence & Cauliflower & Brassica oleracea L. var. Botrytis L. & Brassicaceae \\
\hline
\end{tabular}

Table 2. The mean and SE concentrations $\left(\mu \mathrm{g} \mathrm{g}^{-1}\right)$ of heavy metals in soil of wastewater (WWI) and clean water irrigated (CWI) sites.

\begin{tabular}{ccccccccc}
\hline & \multicolumn{3}{c}{ CWI } & \multicolumn{9}{c}{ WWI } & \multicolumn{2}{c}{ Safe Limits } \\
\cline { 2 - 9 } metals & Range & Mean & SE & Range & Mean & SE & $\begin{array}{c}\text { Indian } \begin{array}{c}\text { International } \\
\text { (European } \\
\text { (Awashthi, 2000) }\end{array} \\
\text { Union, 2002) }\end{array}$ \\
\hline $\mathrm{Cr}$ & $5.65-6.45$ & 6.07 & \pm 0.35 & $12.26-14.84$ & $13.76^{* * *}$ & \pm 1.19 & -- & 150 \\
$\mathrm{Cd}$ & $0.81-2.38$ & 1.41 & \pm 0.68 & $2.68-4.95$ & $3.87^{* *}$ & \pm 0.97 & $3-6$ & 3.0 \\
$\mathrm{Cu}$ & $5.31-6.57$ & 6.06 & \pm 0.57 & $15.23-16.52$ & $15.95^{* * *}$ & \pm 0.56 & $135-270$ & 140 \\
$\mathrm{Fe}$ & $38.69-42.58$ & 40.90 & \pm 1.66 & $221.58-254.26$ & $238.59^{*}$ & \pm 13.37 & $75-150$ & -- \\
$\mathrm{Mn}$ & $7.59-8.65$ & 8.16 & \pm 0.47 & $35.81-42.38$ & $39.19^{* * *}$ & \pm 2.70 & -- & -- \\
$\mathrm{Zn}$ & $7.28-9.52$ & 8.42 & \pm 0.99 & $25.95-28.62$ & $27.12^{* * *}$ & \pm 1.16 & $300-600$ & 300 \\
\hline
\end{tabular}

Student's t-test was done for mean value of heavy metal concentrations between CWI and WWI site..** Level of significance: $p \leq 0.01 .{ }^{* * *}$ Level of significance: $p \leq 0.001$. 
Table 3. The mean and SE concentrations ( $\mu \mathrm{g} g-1)$ of heavy metals in plants of wastewater (WWI) and clean water irrigated (CWI) sites.

\begin{tabular}{lcccccccccccccc}
\hline \multirow{2}{*}{ Plants } & \multicolumn{1}{c}{ WWI } & \multicolumn{1}{c}{ CWI } \\
\cline { 2 - 14 } & $\mathbf{C r}$ & $\mathrm{Cd}$ & $\mathrm{Cu}$ & $\mathrm{Fe}$ & $\mathrm{Mn}$ & $\mathrm{Zn}$ & $\mathrm{Cr}$ & $\mathrm{Cd}$ & $\mathrm{Cu}$ & $\mathrm{Fe}$ & $\mathrm{Mn}$ & $\mathrm{Zn}$ \\
\hline \multirow{2}{*}{ Cabbage } & $3.85 \pm$ & $1.86 \pm$ & $5.35 \pm$ & $39.67 \pm$ & $6.4 \pm 1$. & $8.06 \pm 1$ & $0.56 \pm$ & $0.08 \pm 0$ & $3.62 \pm 0$ & $12.44 \pm 1$ & $3.54 \pm 0$ & $4.15 \pm$ \\
& 0.95 & 0.25 & 1.03 & 2.40 & 03 & .38 & 0.06 & .01 & .69 & .57 & .58 & 0.38 \\
\multirow{3}{*}{ Cauliflower } & $2.54 \pm$ & $0.89 \pm$ & $8.02 \pm$ & $37.12 \pm$ & $6.34 \pm$ & $9.31 \pm 1$ & $0.68 \pm$ & $0.09 \pm 0$ & $2.97 \pm 0$ & $9.12 \pm 0$. & $2.76 \pm 0$ & $3.06 \pm$ \\
& 0.54 & 0.07 & 1.16 & 2.40 & 0.96 & .43 & 0.13 & .02 & .53 & 79 & .37 & 0.39 \\
\multirow{2}{*}{ Spinach } & $2.99 \pm$ & $1.21 \pm$ & $4.98 \pm$ & $30.79 \pm$ & $4.25 \pm$ & $5.60 \pm 1$ & $0.41 \pm$ & $0.05 \pm 0$ & $2.61 \pm 0$ & $9.69 \pm 1$. & $1.67 \pm 0$ & $0.80 \pm$ \\
& 0.15 & 0.19 & 0.84 & 2.10 & 1.21 & .21 & 0.01 & .01 & .32 & 80 & .78 & 0.14 \\
\hline
\end{tabular}

Table 4. Correlation coefficients $\left(r^{2}\right)$ between heavy metals concentrations in the edible parts of the plants and metal concentrations in soil.

\begin{tabular}{lccccccc}
\hline Vegetables & $\mathrm{Cr}$ & $\mathrm{Cd}$ & $\mathrm{Cu}$ & $\mathrm{Fe}$ & $\mathrm{Mn}$ & $\mathrm{Zn}$ \\
\hline Cabbage & -0.68 & -0.62 & 0.91 & -0.34 & 0.74 & -0.98 \\
Cauliflower & -0.06 & -0.06 & 0.67 & -0.34 & -0.43 & 0.05 \\
Spinach & 0.22 & 0.46 & 0.35 & 0.03 & 0.26 & -0.22 \\
\hline
\end{tabular}

Table 5. Enrichment factor of heavy metals in collected foodstuffs from the experimental site.

\begin{tabular}{lcccccc}
\hline Foodstuff's & $\mathrm{Cr}$ & $\mathrm{Cd}$ & $\mathrm{Cu}$ & $\mathrm{Fe}$ & $\mathrm{Mn}$ & $\mathrm{Zn}$ \\
\hline Cabbage & 3.06 & 4.50 & 1.48 & 3.19 & 1.81 & 1.94 \\
Cauliflower & 3.48 & 3.25 & 2.70 & 4.07 & 2.30 & 3.04 \\
Spinach & 2.08 & 2.95 & 1.91 & 3.18 & 2.54 & 7 \\
\hline
\end{tabular}

Table 6. Health risk index (HRI) of heavy metals via intake of foodstuffs from wastewater irrigated sites.

\begin{tabular}{lcccccc}
\hline Foodstuff's & $\mathrm{Cr}$ & $\mathrm{Cd}$ & $\mathrm{Cu}$ & $\mathrm{Fe}$ & $\mathrm{Mn}$ & $\mathrm{Zn}$ \\
\hline Cabbage & 5.47 & 10.88 & 0.59 & 51.92 & 17.22 & 3.08 \\
Cauliflower & 1.66 & 2.30 & 1.71 & 28.33 & 18.71 & 1.42 \\
Spinach & 3.47 & 2.63 & 0.94 & 23.08 & 18.47 & 1.63 \\
\hline
\end{tabular}

WWI

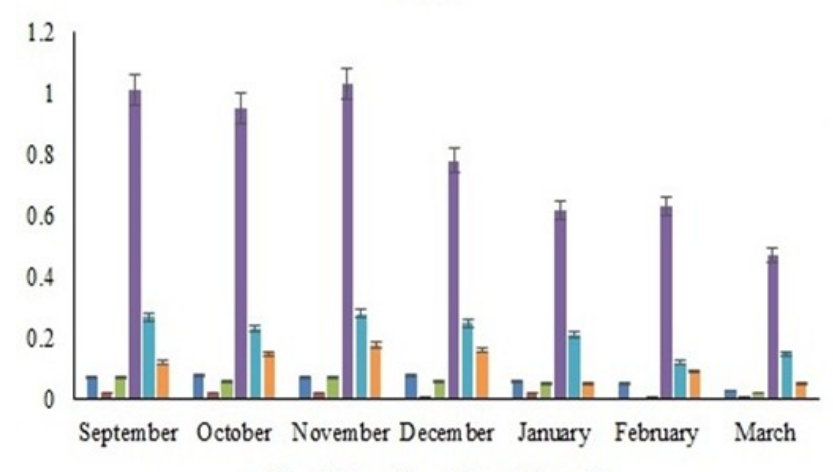

$\approx \mathrm{Cr} \approx \mathrm{Cd} \approx \mathrm{Cu} \approx \mathrm{Fe} \approx \mathrm{Mn} \approx \mathrm{Zn}$
CWI

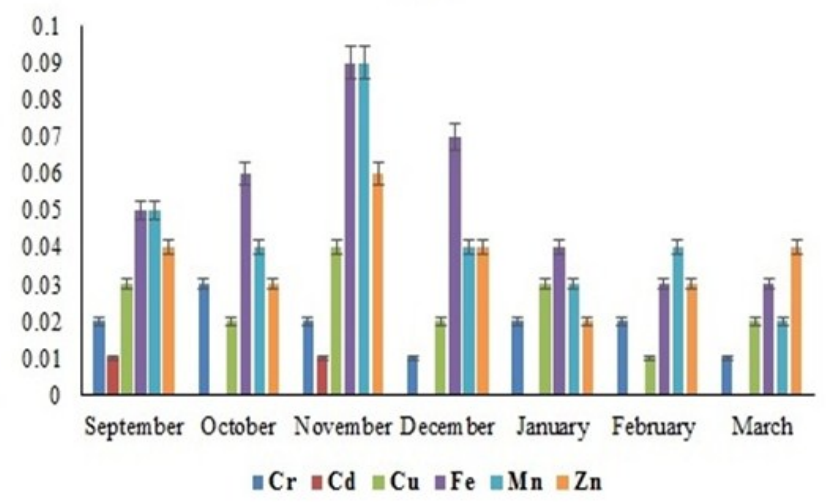

Figure 1. Monthly variations in heavy metal $\left(\mu g g^{-1}\right)$ concentrations of water at WWI and CWI sites.

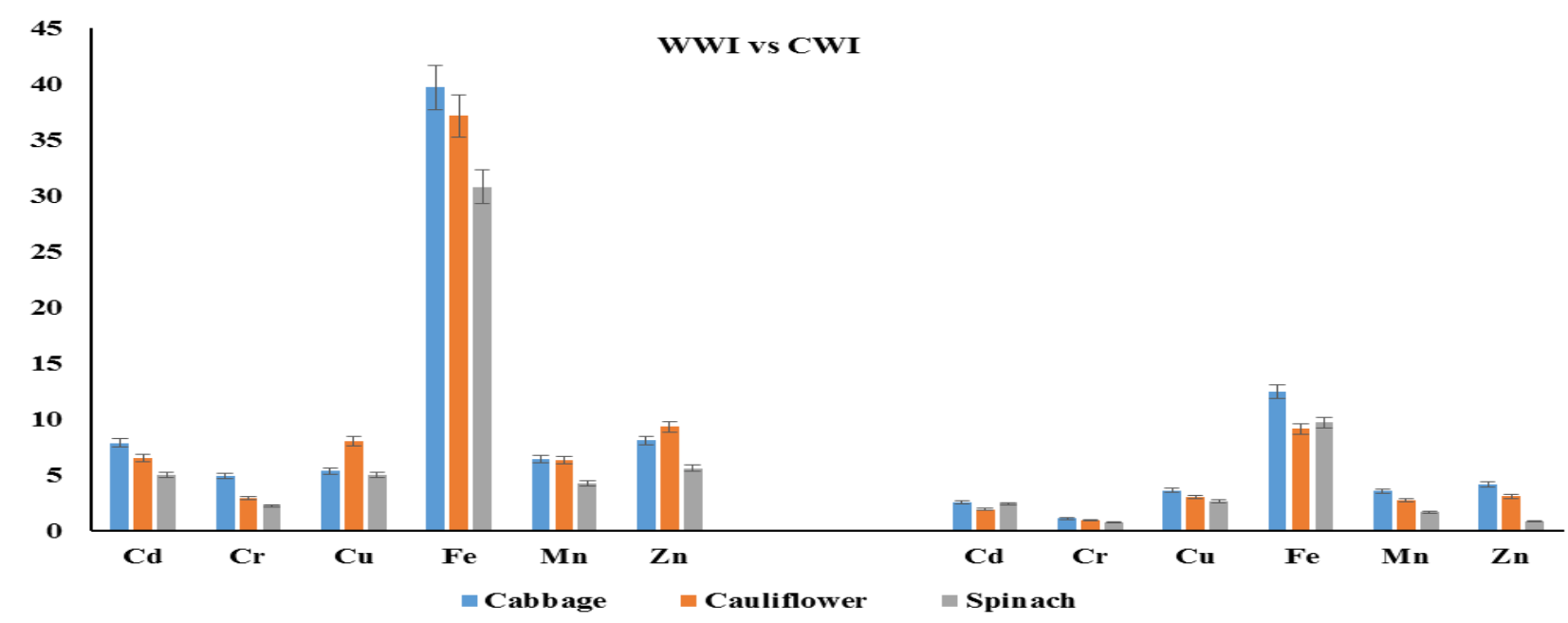

Figure 2. Mean concentration of heavy metals $\left(\mu g g^{-1}\right)$ in plant samples collected from WWI and CWI sites. 


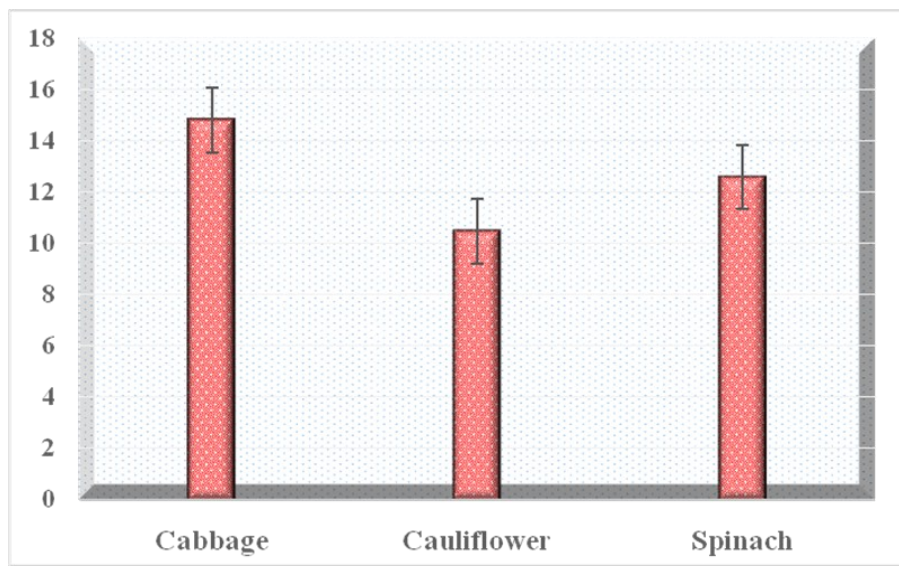

Figure 3. Metal pollution index in different foodstuffs from wastewater irrigated site.

\section{Conclusion}

The result of the study, show that soils in the vicinity of Jagjeetpur area were found to be significantly contaminated with metals. Variations in the heavy metals concentration between the vegetables reflect the variances in uptake abilities and their further translocation to the comestible portion of the plants. Cadmium, Iron and Manganese concentrations were overhead the national and various international tolerable limits in all the vegetables. The metal pollution index and health risk index of heavy metals also recommend that $\mathrm{Cd}$, Fe and Mn adulteration in most of the plants had latent for human health risk due to consumption of plants grown at waste water irrigated site. Cauliflower is found to be slightest contaminated by heavy metals as its metal pollution index and health risk index were lower likened to other foodstuffs. The health risk index was higher in vegetables due to higher proportion in the diet. Ingesting of foodstuff with higher levels of heavy metals may lead to high level of accretion in the body causing related health complaints. The study proposes that even though there are low concentrations of heavy metals in irrigation water, its long term use produced heavy metal contamination leading to health risk of clients. Thus urgent attention is needed to implement suitable means of intensive care and modifiable industrial and domestic effluent, and providing proper advice and support for the safe and fruitful use of wastewater for irrigation.

Open Access: This is open access article distributed under the terms of the Creative Commons Attribution License, which permits unrestricted use, distribution, and reproduction in any medium, provided the original author(s) and the source are credited.

\section{REFERENCES}

Ambika, S.R., Ambica, P.K. and Govindaiah (2010). Crop growth and soil properties affected by sweage water irrigation a review. Agricultural Reviews, 31(3): 203-209.

AOAC (1990). Official methods of Analysis. Method No. 975.03 metal in plants, AAS method, 15th ed. Association of Official Analytical Chemists, Inc., Arlington, pp. 42.
APHA. (2012). Standard methods for the examination of water and waste water, $21^{\text {st }}$ Edn. American Public Health Association, Washington pp. 2462.

Awashthi, S.K. (2000). Prevention of Food Adulteration Act No. 37 of 1954. Central and State rules as amended for 1999 (3rd ed.). New Delhi: Ashoka Law House.

Buat-Menard, P. and Chesselet, R. (1979). Variable influence of the atmospheric flux on the trace metal chemistry of oceanic suspended matter. Earth and Planetary Science Letters, 42 (3): 399-411; https://doi.org/10.1016/0012-821X(79) 90049-9

Carlton-Smith, C.H. and Davis, R.D. (1983). Comparative uptake of heavy metals by forage crops grown on sludge-treated soils. In: Proceeding of International Conference on Heavy metals in the Environment. CEP Consultants Ltd., Edinburg, UK, pp. 3933-3940.

Chary, N.S., Kamala, C.T. and Raj, D.S.S. (2008). Assessing risk of heavy metals from consuming food grown on sewage irrigated soils and food chain transfer. Ecotoxicology and Environmental Safety, 69(3): 513-524; https:// doi.org/10.1016/j.ecoenv.2007.04.013

Chaturvedi, R.K and Sankar, K. (2006). Laboratory manual for the physico-chemical analysis of soil, water and plant. Wildlife Institute of India, Dehradun.

Cui, Y.J., Zhu, Y.G., Zhai, R.H., Chen, D.Y., Huang, Y.Z., Qiu, Y. and Liang, J.Z. (2004). Transfer of metals from soil to vegetables in an area near a smelter in Nanning, China. Environment International, 30(6): 785-791; DOI: 10.1016/ j.envint.2004.01.003

Duruibe, J.O., Ogwuegbu, M.O.C. and Egwurugwu, J.N. (2007). Heavy metal pollution and human biotoxic effects. International Journal of Physical Sciences, 2(5): 112118; http://www.academicjournals.org/IJPS

European Union, (2002). Heavy Metals in Wastes, European Commission on Environment. <http://ec.europa.eu/ environment/waste/studies/pdf/heavymetalsreport.pdf>

Fytianos, K., Katsianis, G., Triantafyllou, P. and Zachariadis, G. (2001). Accumulation of heavy metals in vegetables grown in an industrial area in relation to soil. Bulletin of Environmental Contamination and Toxicology, 67(3): 0423-0430; DOI: 10.1007/s00128-001-0141-8

Ge, K.Y. (1992). The Status of Nutrient and Meal of Chinese in the 1990s. Beijing People's Hygiene Press, pp. 415-434.

Ashok, K., Sharma, I.K., Alka, S., Sarita, V. and Verma, P.S. (2009). Heavy metals contamination of vegetable foodstuffs in Jaipur (India). Electronic Journal of Environmental, Agricultural and Food Chemistry, 8(2): 96-101.

Kumar, V. and Chopra, A.K. (2013). Accumulation and translocation of metals in soil and different parts of French bean (Phaseolus vulgaris L.) amended with sewage sludge. Bulletin of Environmental Contamination and Toxicology, 92(1): 103108; DOI 10.1007/s00128-013-1142-0

Kumar, V. and Thakur, R.K. (2017). Pollution load of SIDCUL effluent with reference to heavy metals accumulated in sediments using pollution load index (PLI) and 
geo-accumulation index (I-geo) at Haridwar (Uttarakhand), India. Journal of Environment and Biosciences, 31(1): 163168.

Kumar, V., Chopra, A.K., Kumar, S., Singh, J. and Thakur, R.K. (2015). Effects of pulp and paper mill effluent disposal on soil characteristics in the vicinity of Uttaranchal Pulp and Paper Mill, Haridwar (Uttarakhand), India. International Journal of Agriculture Science and Research, (4): 117-125.

Kumar, V., Chopra, A.K., Singh, J., Thakur, R.K., Srivastava, S. and Chauhan, R.K. (2016). Comparative assessment of phytoremediation feasibility of water caltrop (Trapa natans L.) and water hyacinth (Eichhornia crassipes Solms.) using pulp and paper mill effluent. Archives of Agriculture and Environmental Science, 1(1): 13-21.

Kumar, V., Chopra, A.K., Srivastava, S., Singh, J. and Thakur, R.K. (2017). Irrigating okra with secondary treated municipal wastewater: Observations regarding plant growth and soil characteristics. International Journal of Phytoremediation, 19 (5): 490-499; https:// doi.org/10.1080/15226514.2016.1244169

Kumar, V., Chopra, A.K., Srivastava S. and Chauhan, R.K. (2015). Accumulation of heavy metals in vegetables grown in wastewater irrigated soil in Haridwar (Uttarakhand), India. Agricultural Science Research Journal, 5(11): 146 -152.

Kumar, V., Srivastava, S., Chauhan, R.K., Thakur, R.K. and Singh, J., (2017). Heavy metals and microbial contamination of certain leafy vegetables grown in abattoir effluent disposal province of Saharanpur (Uttar Pradesh), India. Archives of Agriculture and Environmental Science, 2(1): 36-43.

Kumar, V., Thakur R.K., Singh J. and Singh R. (2016). Effect of sewage effluent disposal on soil characteristics at Haridwar (Uttarakhand), India. World Rural Observations, 8(2): 40-45.

Manios, T., Papagrigoriou, I. and Daskalakis G. (2006). Evaluation of primary and secondary treated and disinfected wastewater irrigation of tomato and cucumber plants under greenhouse conditions, regarding growth and safety considerations. Water Environment Research, 78(8): 797804; http://www.jstor.org/stable/25053584

Mapanda, F., Mangwayana, E.N., Nyamangara, J. and Giller, K.E. (2005). The effect of long-term irrigation using wastewater on heavy metal contents of soils under vegetables in Harare, Zimbabwe. Agriculture, Ecosystems and Environment, 107 (2-3): 151-165; https://doi.org/10.1016/ j.agee.2004.11.005

McCluggage, D. (1991). Heavy Metal Poisoning, NCS Magazine. The Bird Hospital, CO, USA. <www.cockatiels.org/articles/ Diseases/metals.html.

Mireles, A., Solı's, C., Andrade, E., Lagunas-Solar, M., Piña, C. and Flocchini, Rg (2004). Heavy metal accumulation in plants and soil irrigated with wastewater from Mexico City. Nucleus Instrumentation Methods and Physical Research, 219200: 187-90; https://doi.org/10.1016/j.nimb.2004.01.051

Muchuweti, M., Birkett, J.W., Chinyanga, E., Zvauya, R., Scrimshaw, M.D. and Lester, J. N. (2006). Heavy metal content of vegetables irrigated with mixtures of wastewater and sewage sludge in Zimbabwe: implications for human health. Agriculture, Ecosystems and Environment, 112(1): 4148; https://doi.org/10.1016/j.agee.2005.04.028

Nan, Z., Li, J., Zhang, J. and Cheng, G. (2002). Cadmium and zinc interactions and their transfer in soil-crop system under actual field conditions. Science of the Total Environment, 285 (1-3): 187-195; https://doi.org/10.1016/S0048-9697(01) 00919-6

Nanjundappa, G., Reddy, V.C. and Yogananda, S.B. (2002). Performance of fodder grasses on sewage water. Mysore Journal of Agriculture Science, 36(3): 254-256.

Oliveira, A. and Pampulha, M.E. (2006). Effect of long term heavy metal contamination on soil microbial characteristics. Journal of Biosciences and Biological Engineering, 102(3): 157-161; https://doi.org/10.1263/jbb.102.157

Pathak, C., Chopra, A.K., Kumar, V. and Sharma, S. (2011). Effect of sewage-water irrigation on physico-chemical parameters with special reference to heavy metals in agricultural soil of Haridwar city. Journal of Applied and Natural Science, 3(1): 108-113.

Pescod, M.B. (1992). Wastewater treatment and use in agriculture. FAO Irrigation and Drainage Paper 47, Food and Agriculture Organization of the United Nations, Rome.

Raj, R. and Thakur, R.K. (2017). A study on physico-chemical and microbiological parameters of ground water in different locations of Gwalior City (MP), India. Biomedicine and Nursing, 3(1): 19-23.

Rattan, R.K., Datta, S.P., Chhonkar, P.K., Suribabu, K. and Singh, A. K. (2005). Long-term impact of irrigation with sewage effluents on heavy metal content in soils, crops and groundwater-a case study. Agriculture, Ecosystems and Environment, 109(3-4): 310-322; https://doi.org/10.1016/ j.agee.2005.02.025

Rattan, R.K., Datta, S.P., Chandra, S. and Saharan, N. (2002). Heavy metals and environmental quality-Indian scenario. Fertiliser News, 47(11): 21-40.

Singh, P.K., Deshbhratar, P.B. and Ramteke, D.S. (2012). Effects of sewage wastewater irrigation on soil properties, crop yield and environment. Agricultural Water Management, (103): 100-104; $\quad$ https://doi.org/10.1016/ j.agwat.2011.10.022

Tani, F.H. and Barrington, S. (2005). Zinc and copper uptake by plants under two transpiration rates. Part I. Wheat (Triticum aestivum L.). Environmental Pollution, 138(3): 538-547; https://doi.org/10.1016/j.envpol.2004.06.005

Tinker, P.B. (1981). Levels, distribution and chemical forms of trace elements in food plants. Philos. Trans. B 294: 41-55.

USEPA, US Environmental Protection Agency (1997). Exposure Factors Handbook - General Factors. EPA/600/P95/002Fa, vol. I. Office of Research and Development. National Center for Environmental Assessment. US Environmental Protection Agency. Washington, DC. <http:// www.epa.gov/ncea/pdfs/efh/front.pdf>.

USEPA, US Environmental Protection Agency (2002). Region 9, Preliminary Remediation Goals. <http://www.epa.Gov/ 
region09/waste/sfund/prg>.

Usero, J., Gonzalez-Regalado, E. and Gracia, I. (1997). Trace metals in the bivalve molluscs Ruditapes decussatus and Ruditapes philippinarum from the Atlantic Coast of Southern Spain. Environment International, 23(3): 291-298; https:// doi.org/10.1016/S0160-4120(97)00030-5

Wang, G.L. and Lin, W.J. (2003). Contamination of soil from sewage irrigation and its remediation. Journal of Agro-Environment Science, 22(2): 163-166.
Yadav, R.K., Goyal, B., Sharma, R.K., Dubey, S.K. and Minhas, P.S. (2002). Post-irrigation impact of domestic sewage effluent on composition of soils, crops and ground water-a case study. Environment International, 28(6): 481-486; https:// doi.org/10.1016/S0160-4120(02)00070-3

Zhang, Y.L., Wang, D.R.Q. and Zhang, J. (2008). Effect of long term sewage irrigation on agricultural soil in Shandong. Eurasian Journal of Soil Biology, 44(1): 84-91; https:// doi.org/10.1016/j.ejsobi.2007.10.003 